\title{
Relevansi Pembelajaran Pendidikan Agama Islam Berbasis Pengarusutamaan Gender
}

\author{
Rizka Hidayatul Umami \\ Islam dan Kajian Gender, Interdisciplinary Islamic Studies, UIN Sunan Kalijaga \\ J1. Marsda Adisucipto, Yogyakarta, 55281 \\ e-mail: rizkatacin@gmail.com
}

\begin{abstract}
Abstrak: Artikel ini membahas relevansi pembelajaran pendidikan agama Islam berbasis pengarusutamaan gender. Sesuai dengan Instruksi Presiden nomor 9 tahun 2000, sudah semestinya setiap lembaga pemerintah menerapkan pengarusutamaan gender sebagai landasan membuat kebijakan dalam pembangunan. Hal tersebut juga berlaku di lembaga pendidikan, di mana pengarusutamaan gender sudah harus diintegrasikan atau setidaknya berkorelasi dengan kurikulum pembelajaran. Salah satu mata pelajaran wajib yang perlu mengintegrasikan konsep kesetaraan gender dalam pembelajarannya adalah pendidikan agama islam, karena dalam banyak kasus menyebutkan pemahaman agama yang tidak sensitif gender seringkali membawa dampak sosial yang merugikan perempuan, menghadirkan stereotipe, diskriminasi, marginalisasi dan melanggengkan budaya patriarki di masyarakat. Jenis penelitian ini berbasis kepustakaan atau library research dengan metode deskriptif-analitis. Adapun hasilnya menunjukkan bahwa pengarusutamaan gender sangat urgen dimasukkan dalam kurikulum pembelajaran pendidikan agama Islam karena terbukti membawa dampak signifikan dalam perubahan cara pandang pendidik dan peserta didik.
\end{abstract}

\begin{abstract}
This article focuses on the relevance of learning Islamic religious education based on gender mainstreaming. In accordance with Presidential Instruction number 9 of 2000, every government agency should have implemented gender mainstreaming as a basis for making policies in development. This also applies in educational institutions, where gender mainstreaming must be integrated or at least correlated with the learning curriculum. One of the compulsory subjects that need to integrate the concept of gender equality in learning is Islamic religious education, because in many cases it is stated that the understanding of religion that is not gender sensitive often brings social impacts that are detrimental to women, presenting stereotypes, discrimination, marginalization and perpetuates a patriarchal culture in society. Sources of data were obtained from books and journal articles related to the research focus. The results show that gender mainstreaming is very urgent to be included in the Islamic religious education curriculum because it has been proven to have a significant impact in changing the perspectives.
\end{abstract}

Kata Kunci: pengarusutamaan gender, kesetaraan gender, pembelajaran PAI 


\section{Pendahuluan}

Pendidikan merupakan salah satu aspek penting yang memiliki peran strategis dalam pembangunan karakter suatu bangsa. Kualitas pendidikan secara umum ikut menentukan kualitas sumberdaya manusia yang ada di suatu negara, sekaligus berkontribusi pada aspekaspek lain seperti ekonomi, sosial, budaya bahkan partisipasi di bidang politik dan hukum. Dalam undang-undang no. 20/2003 tersebut pada bab I pasal 1, bahwa pendidikan sendiri merupakan sebuah usaha terencana yang dibuat untuk mewujudkan partisipasi aktif peserta didik dalam pembelajaran, sehingga peserta didik mampu mengembangkan potensi yang dimilikinya. ${ }^{1}$ Ketika peserta didik mampu menyadari potensinya dan bersungguh-sungguh mengembangkan potensi tersebut, di masa depan mereka dapat menguasai pengetahuan serta ikut berpartisipasi mewujudkan cita-cita pembangunan, yakni meningkatkan kualitas hidup serta menyejahterakan masyarakat secara keseluruhan. ${ }^{2}$

Selain menyejahterakan hidup, pendidikan juga merupakan sarana dalam mentransformasikan nilai-nilai yang ada di masyarakat, baik nilai-nilai sosial maupun budaya. ${ }^{3}$ Dalam proses transformasi tersebut, pendidikan memiliki tugas membentuk kesadaran peserta didik, baik yang berkaitan dengan cipta, rasa maupun karsa. Adapun untuk membentuk pola kesadaran itu, sekolah dibuat sedemikian rupa sehingga dapat dipakai sebagai ruang yang kondusif untuk proses belajar peserta didik. ${ }^{4}$ Proses belajar dianggap sangat penting bagi orangtua maupun para pendidik karena proses tersebut akan dapat menentukan tingkat pemahaman peserta didik terkait isi materi yang disampaikan. ${ }^{5}$

Namun demikian, pendidikan di Indonesia saat ini tidak bisa lepas begitu saja dari permasalahan. Di Indonesia, mutu pendidikan yang rendah tidak lekas diimbangi dengan upaya-upaya kreatif maupun inovasi, sehingga yang terjadi di daerah -yang notabene minim akses pendidikan, semakin memprihatinkan. Hal tersebut diperparah dengan adanya konflik yang terjadi di dalam ruang akademik, baik yang sifatnya horizontal maupun vertikal ikut menyumbang daftar panjang sulitnya pendidikan di Indonesia mencapai tujuan pendidikan nasional. ${ }^{6}$

Dewasa ini konflik yang terjadi mulai dari tingkat sekolah dasar semakin tidak terkendali. Konflik tersebut tidak hanya menyasar persoalan-persoalan yang sederhana, akan tetapi semakin kompleks dan mengakibatkan tingkat intoleransi di dalam ruang akademik semakin tinggi. Iklim sekolah yang seharusnya kondusif untuk proses belajar mengajar antara guru dengan murid menjadi tidak nyaman dan jauh dari rasa aman. Selain transfer keilmuan terhambat, kompleksitas konflik yang terjadi juga kerap menghadirkan ketidakadilan gender

${ }^{1}$ Ni Made Sri Utami Dewi and A.A. Gede Agung, "Pengaruh Model Pembelajaran Resolusi Konflik Terhadap Hasil Belajar IPS Siswa Kelas V," e-Journal PGSD Universitas Pendidikan Ganesha Jurusan PGSD Vol.4, No.1 (2016), h. 2.

${ }^{2}$ Hadiatul Rodiyah and Wayan Lasmawan, "Pengaruh Model Pembelajaran Resolusi Konflik Terhadap Sikap Sosial Dan Hasil Belajar IPS Kelas V SD Gugus 2 Selong Lombok Timur,” Jurnal Didika Vol.4, No.1 (June 2018), h. 25.

${ }^{3}$ Ribut Purwo Juono, “Kesetaraan Gender Dalam Pendidikan Islam: Studi Pemikiran Pendidikan Hamka Dalam Tafsir al-Azhar,” Analisis: Jurnal Studi Keislaman Vol.15, No.1 (June 2015), h. 122.

${ }^{4}$ Intan Arieyanti and I Wayan Lasmawan, "Pengaruh Model Pembelajaran Resolusi Konflik Dan Sikap Demokrasi Terhadap Hasil Belajar PKn Siswa Kelas VII SMP Negeri 4 Negara - Bali,” e-Journal Program Pascasarjana Universitas Pendidikan Ganesha Jurusan Pendidikan Dasar Vol.3 (2013), h. 2.

5 Apri Wulandari and Suyadi, "Pengembangan Emosi Positif Dalam Pendidikan Islam Perspektif Neurosains," Tadrib Vol.5, No.1 (June 2019), h. 52.

${ }^{6}$ Dewi and Agung, "Pengaruh Model Pembelajaran Resolusi Konflik Terhadap Hasil Belajar IPS Siswa Kelas V.”... h. 2 
di ruang akademik. Pendidikan yang seharusnya mengajarkan peserta didik mengenai pentingnya bersifat humanis dan menjunjung kesetaraan, justru tereduksi menjadi sangat pragmatis, cenderung praktis dan penuh dengan kepentingan-kepentingan golongan yang berjangka pendek ${ }^{7}$ serta melanggengkan praktik ketidakadilan dan ketidaksetaraan peran lakilaki dengan perempuan, bahkan sejak dini. ${ }^{8}$

Dalam konteks persoalan tersebut, keberadaan pembelajaran pendidikan agama Islam juga mengalami ambiguitas peran. Di satu sisi dianggap menjadi alternatif yang bisa dijadikan senjata untuk memutus rantai ketidakadilan gender dan intoleransi yang selama ini tumbuh subur di dalam ruang akademik sekaligus membangun pemahaman keagamaan yang lebih inklusif dan mengedepankan pluralitas. Tapi di sisi lain, realita yang diperoleh dari proses pembelajaran pendidikan agama islam berbicara sebaliknya, yakni semakin memperkeras konflik yang ada dengan menafikan hak agama lain, adanya ajaran yang melegitimasi kebenaran mutlak satu agama, sehingga pembelajaran agama Islam di sekolah nampak eksklusif. $^{9}$

Nilai-nilai yang terkandung dalam ajaran Islam -yang berdasar pada al-Qur'an dan Sunnah, sebenarnya merupakan elemen penting yang dapat digunakan untuk membentuk tatanan masyarakat yang lebih manusiawi dan berkeadilan. ${ }^{10}$ Sebelumnya, sebagaimana yang diketahui pendidikan agama merupakan salah satu mata pelajaran wajib yang strategis guna membangun kehidupan berbanga yang religius. ${ }^{11}$ Lewat pendidikan agama yang inklusif dan mengedepankan keberagaman, diharapkan perilaku peserta didik juga dapat dikendalikan dan bisa menciptakan kepribadian yang menjunjung tinggi pluralitas dan keadilan sesama manusia.

Akan tetapi hal tersebut akan sulit tercapai apabila dalam praktik pembelajaran pendidikan agama Islam di sekolah-sekolah masih menerapkan eksklusivitas dan enggan merevisi muatan materi yang menjurus pada pemahaman keagamaan yang bias gender. Menurut hemat penulis, salah satu langkah relevan yang dapat diambil adalah dengan menyusun ulang isi atau materi dalam pembelajaran pendidikan agama Islam dan mengoptimalkan pendidikan agama Islam yang terintegrasi dengan sistem pembelajaran yang berbasis pengarusutamaan gender. Tulisan ini akan fokus membedah relevansi pembelajaran pendidikan agama Islam berperspektif gender dan urgensinya pada konteks pendidikan masa kini.

${ }^{7}$ Mukhammad Abdullah, "Kontribusi Pendidikan Agama Terhadap Pendidikan Multikultural, Pendidikan Kewarganegaraan Dan Pendidikan Karakter Bangsa: Studi Terhadap Ideologi Pendidikan Islam Di Indonesia,” Didaktika Religia Vol.3, No.1 (2015).

${ }^{8}$ Ali Murfi, "Bias Gender Dalam Buku Teks Pendidikan Agama Islam Dan Kristen," Jurnal Pendidikan Islam Vol.3, No.2 (Desember 2014), h. 269.

9 Erlan Muliadi, "Urgensi Pembelajaran Agama Islam Berbasis Multikultural Di Sekolah," Jurnal Pendidikan Islam Vol.I, No.1 (June 2012), h. 56.

${ }^{10}$ Juono, "Kesetaraan Gender Dalam Pendidikan Islam: Studi Pemikiran Pendidikan Hamka Dalam Tafsir al-Azhar."... h. 122.

11 Dalam penjelasan atas undang-undang tersebut dijelaskan bahwa pendidikan agama dimaksudkan membentuk peserta didik yang beriman, menjadi manusia yang bertakwa dan memiliki akhlak mulia. Lihat Lembaran Negara Republik Indonesia tahun 2003 nomor 78, DPR RI, "Undang-Undang Republik Indonesia Nomor 20 Tahun 2003 Tentang Sistem Pendidikan Nasional,” July 8, 2003, hukum.unsrat.ac.id. 


\section{Metode Penelitian}

Penelitian ini menggunakan jenis penelitian kepustakaan atau library research. Dalam penelitian kepustakaan, penulis menggunakan sumber-sumber berupa buku, artikel jurnal dan dokumen-dokumen yang relevan dalam rangka menunjang terpenuhinya data penelitian. ${ }^{12}$ Adapun penulisan hasil penelitian dilakukan dengan metode deskriptif, yakni berusaha menjelaskan secara rinci atau detail mengenai hasil temuan secara akurat. Hasil temuan tersebut digambarkan secara jelas melalui kata-kata. ${ }^{13}$ Adapun teknik pengumpulan data dilakukan sesuai dengan pendekatan yang digunakan, yakni mencari literatur-literatur yang sejalan dengan kebutuhan penelitian. Kemudian setelah semua data terkumpul, dilakukan analisis mendalam terhadap data-data tersebut, sehingga nantinya diperoleh kesimpulan yang bisa dipertanggungjawabkan. Kaitannya dengan hal tersebut, sumber-sumber data dalam penelitian ini diperoleh dari artikel jurnal yang fokus membahas pembelajaran pendidikan agama Islam, pendidikan agama berperspektif gender dan artikel-artikel lain yang terkait dengan pembahasan tersebut. Hasil dari penelitian ini juga akan disimpulkan ke dalam bentuk yang interpretatif sesuai dengan konteks penelitian. ${ }^{14}$

\section{Hasil dan Pembahasan}

\section{Dinamika Pembelajaran PAI}

Dalam rangka menghadapi era globalisasi yang tidak dapat dibendung, pengajaran pendidikan agama tidak lagi dimaknai sempit hanya sebagai pengenalan ajaran sebuah agama yang dianut oleh masing-masing peserta didik, akan tetapi sudah lebih luas pada penghayatan dan penguatan nilai-nilai kemanusiaan. Di Indonesia sendiri, pendidikan agama memiliki dua fungsi utama, yakni sebagai penguat keimanan peserta didik sesuai dengan agama yang dianutnya dan sebagai sarana meningkatkan sikap saling menghargai, menghormati dan bersikap toleran terhadap adanya perbedaan. Fungsi tersebut berguna dalam rangka memperkokoh persatuan dan kesatuan bangsa Indonesia. ${ }^{15}$

Hadirnya pendidikan agama juga mengemban tanggungjawab menyebar semangat kebangsaan dan kesadaran bahwa perbedaan merupakan anugerah dan sebuah keniscayaan yang harus disikapi secara terbuka. Pendidikan agama, terutama Islam harus mampu menjadi jembatan penghubung atau komunikator yang menyatukan perbedaan-perbedaan dan kemajemukan yang ada di Indonesia dalam payung pluralitas. Secara umum, Pendidikan Agama Islam (PAI) merupakan salah satu mata pelajaran wajib yang yang memiliki posisi krusial dalam sistem pendidikan nasional. PAI juga ada di setiap jenjang pendidikan, mulai dari sekolah dasar, menengah bahkan perguruan tinggi. ${ }^{16}$

Adapun dalam menghadapi perbedaan keyakinan, ada lima tugas utama dan tanggungjawab PAI, sebagaimana disebutkan Amin Abdullah dan dikutip Mahmud Arif

${ }^{12}$ S. Syarnubi, "Guru Yang Bermoral Dalam Konteks Sosial, Budaya, Ekonomi, Hukum Dan Agama (Kajian Terhadap UU No 14 Tahun 2005 Tentang Guru Dan Dosen)," Jurnal PAI Raden Fatah Vol.1, No.1 (2019), h. 22.

${ }^{13}$ Sugiyono, Metode Penelitian Kuantitatif, Kualitatif Dan R\&D (Bandung: Alfabeta, 2009).

${ }^{14}$ Suyitno, Metode Penelitian Kualitatif; Konsep, Prinsip Dan Operasionalnya (Tulungagung: Akademia Pustaka, 2018).

${ }^{15}$ Tarmizi Taher, Menuju Ummatan Wasathan: Kerukunan Beragama Di Indonesia (Jakarta: PPIM IAIN Jakarta, 1998), h. 72-73. Nasional."

${ }^{16}$ DPR RI, "Undang-Undang Republik Indonesia Nomor 20 Tahun 2003 Tentang Sistem Pendidikan 
sebagai berikut; Pertama, PAI memiliki tugas dan tanggungjawab menjadi sarana memahamkan ajaran Islam klasik dan memperkenalkan isu-isu kontemporer kepada tiap-tiap generasi. Kedua, tugas PAI adalah mengarahkan manusia untuk mencari jalan keluar atas segala persoalan yang dihadapi di dunia. Ketiga, PAI memiliki tanggungjawab mengkontekstualisasikan ajaran Islam, sehingga bisa selalu sesuai di segala masa dan dapat menjawab tantangan zaman. Keempat, PAI memiliki tugas mengkritisi ajaran-ajaran agama yang hanya fokus pada persoalan kognitif dan yang meniadakan persoalan-persoalan penting lainnya -seperti transformasi nilai-nilai kemanusiaan, dan lain sebagainya. Kelima, PAI memiliki tugas dan tanggungjawab mengembangkan moralitas individu dan moralitas publik secara beriringan, tidak hanya mementingkan individualitas lantas menafikan moral sosial. ${ }^{17}$

Pada dasarnya, keberadaan PAI diharapkan mampu menanamkan nilai-nilai spiritualitas pada diri setiap peserta didik, sehingga peserta didik dapat menjadi manusia yang menjunjung etika dan akhlak, sesuai dengan tujuan utama dihadirkannya pendidikan nasional. ${ }^{18}$ Dalam lampiran undang-undang nomor 20/2006 juga telah dijelaskan mengenai muatan kurikulum pendidikan agama islam dan tujuan dari diberlakukannya pendidikan agama islam di masingmasing jenjang pendidikan. Salah satu tujuan pembelajaran yang dijelaskan dalam lampiran tersebut yakni menghasilkan peserta didik yang senantiasa menyempurnakan iman, menjadi manusia yang tangguh, baik ketika menghadapi tantangan maupun perubahan pergaulan di masyarakat di tingkat lokal, nasional dan juga global. ${ }^{19}$

Sementara itu dalam proses pelaksanaan pendidikan agama islam selama ini juga tidak lepas dari dinamika, di mana dalam praktik pembelajarannya mengalami pasang surut dan penyesuaian dengan pola kehidupan manusia sehari-hari. Kegagalan mengimplementasikan pendidikan agama islam pada praktik pembinaan akhlak peserta didik juga seringkali membuat pandangan publik terhadap pembelajaran pendidikan agama redup. Transformasi nilai-nilai keagamaan yang harusnya bisa berkorelasi dengan praktik hidup yang penuh tenggangrasa, kejujuran, tanggungjawab, keluhuran, menjadi jarang terlihat dalam keseharian peserta didik. Adapun yang terlihat justru sebaliknya, yakni cara pandang peserta didik yang bias, mengunggulkan kebenaran agama yang dianut dan cenderung memberi stigma pada agama lain, memiliki sikap merendahkan orang lain yang berbeda dengannya atau dengan kelompok yang diikutinya, hingga gagal memahami persoalan sosial, lebih mementingkan kepentingan individu dan mengukuhkan peran-peran yang timpang di masyarakat, terutama antara laki-laki dan perempuan. ${ }^{20}$

Salah satu contoh hadirnya ketimpangan di ruang akademik kaitannya dengan pembelajaran PAI adalah dalam buku-buku ajar atau kurikulum pendidikan agama Islam yang digunakan. Hal tersebut sebagaimana hasil penelitian Nanik Setyowati terhadap teks materi pelajaran PAI di SD Ma'arif Ponorogo, yang menyebutkan bahwa ada dominasi peran lakilaki terhadap perempuan dalam buku-buku ajar tersebut. Adapun prosentase dominasinya bisa mencapai $90 \%$ di mana penggambaran tokoh perempuan dalam bahan ajar tersebut dikesankan selalu dalam posisi kelas dua, kalah dan lemah. Frekuensi pemunculan tokoh laki-

${ }^{17}$ Mahmud Arif, "Pendidikan Agama Islam Inklusif-Multikultural,” Jurnal Pendidikan Islam Vol.I, No.1 (June 2012), h. 11.

${ }^{18}$ Nur Ainiyah, "Pendidikan Karakter Melalui Pendidikan Agama Islam," Jurnal Al-Ulum (Jurnal StudiStudi Islam) IAIN Gorontalo Vol.13, No.1 (June 2013), h. 30.

19 "Permendiknas No 22 Tahun 2006, Tentang Standar Isi Untuk Satuan Pendidikan Tingkat Dasar Dan Menengah,"... h. 2.

20 Nanik Setyowati, "Pendidikan Gender Dalam Islam: Studi Analisis Nilai-Nilai Kesetaraan Gender Dalam Pelajaraan PAI Di SD Ma'arif Ponorogo," SCAFFOLDING: Jurnal Pendidikan Islam dan Multikulturalisme Vol.1, No.1 (June 2019), h. 40. 
Journal of Islamic Education Policy Vol. 4 No. 1 Januari - Juni 2019

laki dalam cerita, nama maupun peran lebih tinggi dibandingkan pemunculan peran perempuan, terutama ketika membahas masalah kepemimpinan, sehingga jauh dari seimbang. ${ }^{21}$

Selain itu, banyaknya kasus pembulian, pembagian peran di kelas yang tidak imbang atau tidak adil antara peserta didik laki-laki dengan peserta didik perempuan, sampai kasus pelecehan yang sering mengancam peserta didik perempuan dan anak-anak secara umum juga merupakan bukti bahwa pembelajaran pendidikan agama selama ini belum sensitif gender. Pelajaran PAI belum sepenuhnya menerapkan pengarusutamaan gender dalam kurikulumnya. ${ }^{22}$ Kiranya kasus yang ada di salah satu sekolah dasar di Ponorogo juga hanya contoh kecil dari banyaknya sekolah-sekolah yang masih menerapkan gaya kepemimpinan paternalistik dan belum menganggap penting adanya pengarusutamaan gender dalam proses pembelajaran pendidikan agama.

\section{Urgensi Pengarusutamaan Gender}

Secara umum, gender dapat dipahami sebagai sebuah konsep budaya yang membedakan peran, mentalitas sampai emosionalitas laki-laki dan perempuan. ${ }^{23}$ Gender juga merupakan perbedaan tanggungjawab dan peran yang dilekatkan kepada laki-laki dan perempuan berdasarkan konstuksi sosial, di mana konstruk tersebut seharusnya bersifat tidak tetap, dinamis dan bisa dipertukarkan sesuai konteks budaya, latar dan waktu. Gender berbeda dengan seks. Jika seks berkaitan erat dengan perbedaan keadaan biologis yang diterima lakilaki dan perempuan, maka gender adalah perbedaan yang bisa dilihat dari segi tingkah laku dan nilai-nilai yang diterima di tengah masyarakat dan merupakan hasil konstruksi sosial budaya. $^{24}$

Selama ini, pemahaman terkait gender seringkali disalahtafsirkan oleh beberapa kalangan sehingga memicu banyak kesalahpahaman dan ketidakberterimaan waawasan mengenai gender dalam ruang akademik. Imam Machali, sebagaimana dikutip Ali Murfi mengatakan bahwa yang dimaksud dengan gender merupakan konsep yang dipakai untuk mengidentifikasi perbedaan peran dan status laki-laki dan perempuan, di mana perbedaan sosial yang terjadi adalah hasil perbedaan jenis kelamin yang dikukuhkan statusnya oleh sistem sosial masyarakat. ${ }^{25}$ Ini membuat peran yang harusnya sangat cair antara laki-laki dan perempuan, menjadi beku dan apabila ada peran dominan yang biasanya dikerjakan laki-laki kemudian pada suatu waktu dilakukan oleh perempuan, dianggap tidak pantas, tabu, tidak layak dan lain sebagainya.

Perspektif yang keliru tersebut yang mesti didefinisikan ulang dan dipahami sejak dini, yakni lewat pembelajaran pendidikan agama islam mulai dari jenjang sekolah dasar, menengah, sampai perguruan tinggi. Konsep kesetaraan gender perlu ditanamkan sejak dini agar dalam kehidupan di masa depan, peserta didik baik perempuan dan laki-laki dapat memperoleh kesempatan yang sama dalam berperan dan berpartisipasi di semua bidang

${ }^{21}$ Nanik Setyowati, "Pendidikan Gender Dalam Islam: Studi Analisis Nilai-Nilai Kesetaraan Gender Dalam Pelajaraan PAI Di SD Ma'arif Ponorogo," SCAFFOLDING: Jurnal Pendidikan Islam dan Multikulturalisme Vol.1, No.1 (June 2019), h. 42.

${ }^{22}$ Mohammad Muchlis Solichin, "Pendidikan Agama Islam Berbasis Kesetaraan Gender," Tadris Vol.1, No.1 (2006), h. 55.

${ }^{23}$ Hasbi Indra, dkk, Potret Wanita Shalehah (Jakarta: Penamadia, 2005), h. 243.

${ }^{24}$ Dalam Bab 1 Ketentuan Umum pasal 1 poin pertama dijelaskan mengenai apa yang disebut dengan gender. Lihat: "Rancangan Undang-Undang Tentang Kesetaraan Dan Keadilan Gender," Desember 2013, h. 2.

${ }^{25}$ Murfi, “Bias Gender Dalam Buku Teks Pendidikan Agama Islam Dan Kristen.”... h. 270 
kehidupan, baik di bidang ekonomi, politik, sosial, pendidikan maupun budaya. ${ }^{26}$ Implementasi pengarusutamaan gender di berbagai lembaga pemerintahan dan terutama ruang akademik dalam beberapa dekade terakhir juga telah menjadi wacana serius yang digelontorkan pemerintah sekaligus menjadi kontrol dalam kehidupan sosial.

Jika mengacu Inpres nomor 9/2000, pengarusutamaan gender sudah seharusnya diggunakan sebagai strategi pembangunan nasional. Sebab dalam Instruksi Presiden tersebut kebijakan pengarusutamaan gender sudah dibahas secara spesifik menjadi prinsip dan landasan operasional dalam pelaksanaan pembangunan lintas bidang secara keseluruhan. ${ }^{27}$ Dalam inpres tersebut juga disebutkan bahwa yang dimaksud dengan kesetaraan gender adalah kondisi yang sama antara laki-laki dan perempuan dalam mendapatkan pemenuhan hak dan juga kesempatan sebagai manusia untuk berperan dan menikmati hasil pembangunan nasional. Kesetaraan gender tidak berarti menyamaratakan laki-laki dan perempuan, akan tetapi kesetaraan gender berupaya membangun nilai-nilai yang setara, sehingga baik perempuan maupun laki-laki bisa mendapat perlakuan yang sama. ${ }^{28}$

Dalam Islam, konsep kesetaraan gender sudah tertanam dengan jelas dalam ayat-ayat alQur'an. Misalkan dalam QS. Adz-Dzariyat: 56,

$$
\text { وما خلقت الجن والإنس الا ليعبدون (56) }
$$

\section{Dan Aku tidak menciptakan Jin dan Manusia melainkan supaya mereka mengabdi} kepada-Ku.

Selain itu, dalam QS. Al-An'am: 165 juga disebutkan bahwa baik laki-laki maupun perempuan, sama-sama diciptakan oleh Allah untuk menjadi khalifah di bumi. Amanah yang dititipkan Allah kepada manusia ketika perjanjian primordial antara manusia dan Tuhan terjadi -sebelum mereka dilahirkan, juga tidak hanya terkhusus pada laki-laki, akan tetapi juga pada perempuan. Maka atas dasar itulah, Islam sesungguhnya sudah sangat lekat dengan konsep kesetaraan gender. Tinggal bagaimana kemudian konsep tersebut diimplementasikan dalam proses pembelajaran pendidikan agama Islam di sekolah-sekolah, sehingga nilai-nilai kesetaraan tersebut dapat ditransformasikan seutuhnya ke dalam kehidupan sehari-hari para peserta didik. $^{29}$

Pengarusutamaan gender dalam lembaga pendidikan sangat penting diterapkan secara utuh untuk bisa menghapus stereotipe, stigma terhadap perempuan, eksklusivisme dan budaya patriarki yang masih langgeng di dalam sistem. ${ }^{30}$ Di sini pendidikan memang menjadi kunci utama terwujudnya ikhtiar keadilan dan kesetaraan gender selama ini. Dipilihnya lembaga pendidikan tidak lain karena selama ini pendidikan juga telah banyak membantu mentransformasikan nilai-nilai baru sekaligus ruang untuk mengkaji ide-ide yang

\footnotetext{
${ }^{26}$ Setyowati, "Pendidikan Gender Dalam Islam: Studi Analisis Nilai-Nilai Kesetaraan Gender Dalam Pelajaraan PAI Di SD Ma'arif Ponorogo.”... h. 37.

27 Dian Martiany, "Implementasi Pengarusutamaan Gender (PUG) Sebagai Strategi Pencapaian Kesetaraan Gender (Studi Di Provinsi Sumatera Utara Dan Jawa Tengah)," Aspirasi Vol.2, No.2 (Desember 2011), h. 122.

28 Dian Martiany, "Implementasi Pengarusutamaan Gender (PUG) Sebagai Strategi Pencapaian Kesetaraan Gender (Studi Di Provinsi Sumatera Utara Dan Jawa Tengah)," Aspirasi Vol.2, No.2 (Desember 2011), h. 123.

${ }^{29}$ Setyowati, "Pendidikan Gender Dalam Islam... h.39.

${ }^{30}$ Muliadi, "Urgensi Pembelajaran Agama Islam Berbasis Multikultural Di Sekolah... h.60.
} 
Journal of Islamic Education Policy Vol. 4 No. 1 Januari - Juni 2019

kontekstual. $^{31}$ Ketika pendidikan agama islam telah sepenuhnya sensitif terhadap isu-isu ketimpangan gender, maka wawasan pendidik dan peserta didik mengenai urgensi kesetaraan juga akan memengaruhi arah dan tujuan pendidikan. ${ }^{32}$

Implementasi pengarusutamaan gender dalam pendidikan agama islam dapat dimulai dengan mengintegrasikannya di dalam kurikulum pembelajaran PAI secara betahap di masing-masing jenjang. Empat tingkatan atau level integratif yang bisa dilakukan antara lain adalah contribution approach, additive approach, transformational approach, dan social action approach. Di tingkat pertama, sekolah atau lembaga terkait bisa mulai memasukkan isu-isu berbasis gender ke dalam kurikulum pembelajaran. Di tingkat kedua, ide-ide mengenai pengarusutamaan gender dapat dikorelasikan dengan kurikulum yang sudah ada. Pada tingkat ketiga, lembaga bisa merombak kurikulum lama dan menggantinya dengan muatan yang lebih sensitif terhadap gender. Baru kemudian di tingkat keempat, peserta didik diajak mendiskusikan persoalan-persoalan terkait ketidakadilan gender yang selama ini ada di sekitar mereka, peserta didik juga bisa diajarkan bagaimana mengambil tindakan dan keputusankeputusan yang lebih sensitif gender dan belajar mengimplementasikannya dalam kehidupan sehari-hari. ${ }^{33}$

\section{Relevansi Pembelajaran PAI Berbasis PUG}

Sebagai agama yang diyakini membawa rahmat bagi seluruh alam semesta, dalam ajaran Islam juga tegas mengakui keutuhan manusia perempuan sama dengan keutuhan kemanusiaan laki-laki. Keduanya setara di hadapan Allah dan tidak ada pengkhususan atau keutamaan yang ditujukan hanya untuk salah satu dari dua jenis kelamin tersebut. Namun sebagaimana dikutip Hj. Lift Anis, bahwa dalam proses penafsiran al-Qur'an, masih banyak ulama yang mendistorsi makna yang terkandung dalam suatu ayat, sehingga yang tampil ke permukaan adalah hasil penafsiran yang bias dan tidak mencerminkan keadaan yang setara antara perempuan dan laki-laki. ${ }^{34}$ Penafsiran al-Qur'an yang bersifat subjektif dan relatif tersebut tidak bisa dihindarkan, meskipun al-Qur'an sendiri bersifat tetap dan mengandung kebenaran yang abadi.

Penafsiran terhadap teks-teks keagamaan yang memang subjektif tersebutlah yang dibahas dalam kurikulum pembelajaran pendidikan agama. Ketika hasil pemahaman keagamaan yang dibawa merupakan pemahaman dari hasil tafsir yang bias gender, maka bahan ajar atau materi dari kurikulum pembelajaran yang sampai kepada peserta didik juga bias. Pendidik dan lembaga di sini memiliki tanggungjawab dalam rangka merombak bahan ajar yang bias tersebut sehingga bisa memberi pemahaman baru yang lebih sensitif gender kepada peserta didik. Banyaknya persoalan ketidakadilan gender yang masih langgeng sampai hari ini membuat pengarusutamaan gender di lembaga pendidikan sangat relevan diterapkan guna mengubah semua tatanan dan pola pikir yang tidak sensitif gender.

Perombakan kurikulum menjadi aspek yang krusial untuk segera dilakukan ketika melihat sumber dari ketimpangan yang ada juga berasal dari muatan ajar pembelajaran, yang didapatkan peserta didik di dalam ruang akademik. Pengarusutamaan gender di dalam

${ }^{31}$ Solichin, "Pendidikan Agama Islam Berbasis Kesetaraan Gender."... h. 56

32 Setyowati, "Pendidikan Gender Dalam Islam: Studi Analisis Nilai-Nilai Kesetaraan Gender Dalam Pelajaraan PAI Di SD Ma'arif Ponorogo.”... h. 42

${ }^{33}$ Solichin, "Pendidikan Agama Islam Berbasis Kesetaraan Gender.”... h. 58-59.

${ }^{34}$ Lift Anis Ma'shumah, “Teks-Teks Keislaman Dalam Kajian Feminisme Muslim: Telaah Metodologis Atas Pandangan Feminis Muslim Terhadap Penciptaan Dan Kepemimpinan Perempuan,” Sawwa Vol.7, No.2 (2012) 
pembelajaran pendidikan agama Islam harus mulai dilakukan dengan cara menanamkan terlebih dahulu kepada para pendidik, soal konsep kesetaraan gender di bidang pendidikan. ${ }^{35}$ Lembaga pendidikan juga perlu merekonstruksi paradigma berpikir menjadi lebih inklusif, transformatif dan berwawasan gender dengan tujuan semata-mata memberikan kesempatan yang sama kepada peserta didik baik perempuan maupun laki-laki untuk bisa mengembangkan kreativitas dan potensi yang dimilikinya. Dengan begitu, peserta didik yang telah berhasil mengembangkan potensinya juga akan memiliki kesempatan yang sama dalam medapatkan pekerjaan atau cita-cita lain sesuai dengan kemampuan masing-masing.

Penerapan strategi pengarusutamaan gender dalam pembelajaran pendidikan agama Islam sangat relevan untuk mengurangi tingkat diskriminasi terhadap peserta didik perempuan tidak hanya di bangku sekolah, tapi juga ketika peserta didik tersebut kembali ke masyarakat. Ketika sensitivitas pendidik dan peserta didik terhadap masalah-masalah gender terasah, akan sangat mudah menggeser persepsi masyarakat selama ini yang masih kukuh dalam budaya patriarki dan sering mendiskreditkan peran perempuan di masyarakat dan di ruang publik. Terlebih ketika berkaitan dengan kepemimpinan. Persepi bahwa perempuan tidak layak menjadi pemimpin perlu digeser lewat pembelajaran pendidikan agama Islam yang menerapkan konsep kesetaraan gender di dalamnya, sehingga peserta didik perempuan bisa lebih berani dan optimis ketika memiliki cita-cita atau keinginan menjadi seorang pemimpin. ${ }^{36}$ Selain itu, tingginya tingkat pernikahan anak usia dini juga bisa diturunkan bahkan dicegah pelaksanaannya ketika masing-masing peserta didik serta masyarakat secara umum telah memahami konsep kesetaraan gender dan bagaimana ketidakadilan gender itu bisa terjadi di sekitar mereka.

\section{Penutup}

Pendidikan agama Islam merupakan mata pelajaran yang sangat berperan dalam proses transformasi nilai-nilai agama, sosial dan budaya sekaligus kepada peserta didik. Oleh sebab itu, muatan isi atau materi yang dipelajari oleh peserta didik juga sangat berpengaruh terhadap cara pandang mereka ketika nanti kembali ke masyarakat. Selama ini pemahamaan keagamaan yang kaku dan bias gender langgeng di masyarakat, salah satunya adalah karena pembelajaran yang dilakukan sejak di dalam ruang kelas juga sudah menanamkan konsepkonsep yang bias dan timpang. Hal ini terbawa oleh peserta didik sampai ke lingkungan tempat tinggalnya sehingga semakin mengukuhkan budaya patriarki yang sejatinya jauh dari kesetaraan gender.

Strategi pengarusutamaan gender kemudian menjadi aspek penting yang harus diintegrasikan ke dalam proses pembelajaran pendidikan agama Islam untuk meredam ketimpangan yang selama ini terjadi. Penanaman konsep kesetaraan gender sejak dini menjadi agenda krusial yang mesti diimplementasikan ke dalam kurikulum pembelajaran dalam setiap jenjang pendidikan, guna mengasah sensitivitas peserta didik terhadap persoalan gender yang ada di sekitar mereka. Lembaga pendidikan dan para pendidik memiliki tanggungjawab

\footnotetext{
${ }^{35}$ Juono, "Kesetaraan Gender Dalam Pendidikan Islam: Studi Pemikiran Pendidikan Hamka Dalam Tafsir al-Azhar."

${ }^{36}$ Menurut Husein Muhammad, sebagaimana dikutip Ma'shumah, dalam kepemimpinan ada dua hal yang esensial, yakni aspek kemampuan dan intelektualitas. Dua hal tersebut bisa dimiliki oleh siapapun, baik laki-laki maupun perempuan. Lihat: Ma'shumah, "Teks-Teks Keislaman Dalam Kajian Feminisme Muslim: Telaah Metodologis Atas Pandangan Feminis Muslim Terhadap Penciptaan Dan Kepemimpinan Perempuan.”... h.89.
} 
Journal of Islamic Education Policy Vol. 4 No. 1 Januari - Juni 2019

memahamkan peserta didik akan pentingnya memiliki wawasan gender dalam menjalankan kehidupan bermasyarakat.

Sampai hari ini penerapan pembelajaran pendidikan agama Islam berbasis pengarusutamaan gender juga masih sangat relevan dilakukan, mengingat tingkat diskriminasi, subordinasi, marjinalisasi, pelecehan bahkan kekerasan terhadap perempuan dan anak masih tinggi. Implementasi pengarusutamaan gender dalam pembelajaran pendidikan agama Islam, diharapkan mampu merombak pemahaman keagamaan yang selama ini bias gender menjadi lebih sensitif gender dan bisa merubah cara pandang masyarakat yang patriarkis menjadi masyarakat yang bisa menjunjung keadilan dan kesetaraan dalam menjalani kehidupan sehari-hari. Relevansi penerapan pembelajaran pendidikan agama berbasis pengarusutamaan gender juga terlihat pada meningkatnya minat peserta didik perempuan melanjutkan pendidikan ke jenjang yang lebih tinggi dan terjalinnya optimisme mendapatkan kesempatan yang sama dengan laki-laki, menurunnya tingkat pernikahan anak di bawah umur dan terlaksananya pendidikan yang lebih inklusif dan berkeadilan.

Selama ini, pengarusutamaan gender belum sepenuhnya diimplementasikan dalam pembelajaran di sekolah dasar, menengah bahkan di perguruan tinggi sekalipun. Maka dibutuhkan kerjasama dari berbagai pihak untuk bisa mengintegrasikannya dalam proses pembelajaran, terutama dalam mata pelajaran pendidikan agama Islam. Bagi peneliti selanjutnya disarankan agar menggunakan cara pandang yang responsif gender, dalam mengkaji permasalahan pendidikan agama Islam.

\section{Daftar Pustaka}

Abdullah, Mukhammad. "Kontribusi Pendidikan Agama Terhadap Pendidikan Multikultural, Pendidikan Kewarganegaraan Dan Pendidikan Karakter Bangsa: Studi Terhadap Ideologi Pendidikan Islam Di Indonesia.” Didaktika Religia Vol.3, No.1 (2015): 1-32.

Ainiyah, Nur. "Pendidikan Karakter Melalui Pendidikan Agama Islam.” Jurnal Al-Ulum (Jurnal Studi-Studi Islam) IAIN Gorontalo Vol.13, No.1 (June 2013).

Arieyanti, Intan, and I Wayan Lasmawan. "Pengaruh Model Pembelajaran Resolusi Konflik Dan Sikap Demokrasi Terhadap Hasil Belajar PKn Siswa Kelas VII SMP Negeri 4 Negara - Bali." e-Journal Program Pascasarjana Universitas Pendidikan Ganesha Jurusan Pendidikan Dasar Vol.3 (2013).

Arif, Mahmud. "Pendidikan Agama Islam Inklusif-Multikultural." Jurnal Pendidikan Islam Vol.I, No.1 (June 2012):

Dewi, Ni Made Sri Utami, and A.A. Gede Agung. "Pengaruh Model Pembelajaran Resolusi Konflik Terhadap Hasil Belajar IPS Siswa Kelas V.” e-Journal PGSD Universitas Pendidikan Ganesha Jurusan PGSD Vol.4, No.1 (2016):

DPR RI. "Undang-Undang Republik Indonesia Nomor 20 Tahun 2003 Tentang Sistem Pendidikan Nasional," July 8, 2003. hukum.unsrat.ac.id.

Indra, Hasbi, and dkk. Potret Wanita Shalehah. Jakarta: Penamadia, 2005. 
Juono, Ribut Purwo. "Kesetaraan Gender Dalam Pendidikan Islam: Studi Pemikiran Pendidikan Hamka Dalam Tafsir al-Azhar.” Analisis: Jurnal Studi Keislaman Vol.15, No.1 (June 2015):

Martiany, Dian. "Implementasi Pengarusutamaan Gender (PUG) Sebagai Strategi Pencapaian Kesetaraan Gender (Studi Di Provinsi Sumatera Utara Dan Jawa Tengah)." Aspirasi Vol.2, No.2 (Desember 2011.

Ma'shumah, Lift Anis. "Teks-Teks Keislaman Dalam Kajian Feminisme Muslim: Telaah Metodologis Atas Pandangan Feminis Muslim Terhadap Penciptaan Dan Kepemimpinan Perempuan." Sawwa Vol.7, No.2 (2012):

Muliadi, Erlan. "Urgensi Pembelajaran Agama Islam Berbasis Multikultural Di Sekolah." Jurnal Pendidikan Islam Vol.I, No.1 (June 2012):

Murfi, Ali. "Bias Gender Dalam Buku Teks Pendidikan Agama Islam Dan Kristen.” Jurnal Pendidikan Islam Vol.3, No.2 (Desember 2014):

Rodiyah, Hadiatul, and Wayan Lasmawan. "Pengaruh Model Pembelajaran Resolusi Konflik Terhadap Sikap Sosial Dan Hasil Belajar IPS Kelas V SD Gugus 2 Selong Lombok Timur." Jurnal Didika Vol.4, No.1 (June 2018):

Setyowati, Nanik. "Pendidikan Gender Dalam Islam: Studi Analisis Nilai-Nilai Kesetaraan Gender Dalam Pelajaraan PAI Di SD Ma'arif Ponorogo." SCAFFOLDING: Jurnal Pendidikan Islam dan Multikulturalisme Vol.1, No.1 (June 2019):

Solichin, Mohammad Muchlis. "Pendidikan Agama Islam Berbasis Kesetaraan Gender." Tadris Vol.1, No.1 (2006):

Sugiyono. Metode Penelitian Kuantitatif, Kualitatif Dan R\&D. Bandung: Alfabeta, 2009.

Suyitno. Metode Penelitian Kualitatif; Konsep, Prinsip Dan Operasionalnya. Tulungagung: Akademia Pustaka, 2018.

Syarnubi, S. "Guru Yang Bermoral Dalam Konteks Sosial, Budaya, Ekonomi, Hukum Dan Agama (Kajian Terhadap UU No 14 Tahun 2005 Tentang Guru Dan Dosen).” Jurnal PAI Raden Fatah Vol.1, No.1 (2019): 21-40.

Taher, Tarmizi. Menuju Ummatan Wasathan: Kerukunan Beragama Di Indonesia. Jakarta: PPIM IAIN Jakarta, 1998.

Wulandari, Apri, and Suyadi. "Pengembangan Emosi Positif Dalam Pendidikan Islam Perspektif Neurosains.” Tadrib Vol.5, No.1 (June 2019):

"Permendiknas No 22 Tahun 2006, Tentang Standar Isi Untuk Satuan Pendidikan Tingkat Dasar Dan Menengah," n.d.

“Rancangan Undang-Undang Tentang Kesetaraan Dan Keadilan Gender,” Desember 2013. 